\title{
The Use of Interactive Technologies in the Training of Design Students at the Don State Technical University
}

\author{
Berdnik T.O. \\ Department of Design \\ Don State Technical University \\ Rostov-on-Don, Russia \\ tatiana@berdnik.me
}

\author{
Klimenko I.A. \\ Department of Design \\ Don State Technical University \\ Rostov-on-Don, Russia \\ ir.klimenko@icloud.com
}

\author{
Sayapina L.Yu. \\ Department of Design \\ Don State Technical University \\ Rostov-on-Don, Russia, \\ lara-s12@rambler.ru
}

\begin{abstract}
The article presents traditional models of teaching university students. The necessity of modernization of pedagogical technologies and approaches is substantiated in the context of changes in communication processes in the era of the information society. The author studies the historical experience of the first higher architectural and design school of Bauhaus, which laid the foundations of interactive technologies in art education. The importance of the pedagogical concepts of Bauhaus professors for development of design and the relevance of these concepts in modern design education are considered. Interactive teaching model is presented as the most effective method in the process of professional training of students-designers. In the article features and forms of this model are studied. As an example that demonstrates the diversity of implementation of its forms the experience of professional training of design students who study at the Don State Technical University is under investigation. Such interactive technologies as course design project, performance of independent works and creative tasks, public presentation of the project results are described. There are goals of the creative practice "workshop", the program of which is the author's development of the teachers of the University. The importance of attracting students to the preparation and conduct of cultural mass creative activities with the aim to increase the motivation of their educational activities is particularly emphasized. It is concluded that the interactive methods in education contribute to a high quality training of professionals and cultivation of their active citizenship.
\end{abstract}

Keywords-educational technologies; interactive learning model; design education; competence; student.

\section{INTRODUCTION}

In the age of information society education is undergoing an active modernization. Appearance and continual improvement of forms and sources of information make education look for new teaching technologies. The key innovation in the sphere of education is the fundamental change of the student's role in the process of development of his professional knowledge and skills as he turned from a passive learner into an active learner. Now the task of university education is to motivate the student for independent learning and development of a skill to analyze the knowledge that he gains and use it with benefit for his becoming a professional. In other words, developmental education is becoming the priority. This is the reason why self-organization and self-education ability is included in the list of mandatory competencies of the Russian Federal State Standard. [1].

\section{METHODOLOGY}

The goal of the research is the analysis of the traditional models of teaching in the context of their efficiency in the didactic process and in defining of a place of the interactive teaching technologies in student-designers' development of competencies. To achieve this goal the following methods were used: historical-analytical method, empirical research method and inductive generalization method.

The active position of a modern student requires the university teacher to use new effective pedagogical methods based not on mentoring, but on partnership. It is known that there are three teaching models in the pedagogical activity of the university teacher. The first one is a passive teaching model. In this case the role of the student is reduced to perception of information transmitted by the teacher. Such model is implemented in the form of a classical lecture-monologue of the teacher where the student only watches, listens and remembers.

The second teaching model is active. In this situation the student not only receives new knowledge from the teacher, but 
also applies it in his practical activities, consistently forming a professional skill. Such model is used in practical classes and laboratory practicals, during creative workshops and production technological practical trainings as well as in performing independent work.

In modern education the most effective model is the third that is called interactive. The essence of this educational model is that in the learning process the student actively interacts with both the teacher and students in his group. He participates in discussions, makes presentations, learns to model life and professional situations, etc. [2]. This model relates to developmental teaching and teaches the future professional to work in a team, reach decisions and be responsible for them, and plan the work process. In the design education all three models are present but in different percentage correlation. The realities of the current policy in education shift an emphasis on the use of interactive technologies. This concept is especially relevant in the training of designers. [3].

Interactive teaching is a modern educational trend which nevertheless has more than a century of experience. During the celebration of the centenary of the Bauhaus Higher School of Design it is appropriate to turn to its advanced for its time pedagogical approaches which haven't lost their relevance in modern times. The Bauhaus is a higher school of architecture and art which became the founder of design education. In 1919 a school of architecture and art was founded in the German city of Weimar. It promoted new ideas in the art of shaping that were close to the project principles of emerging design. Walter Gropius, the first rector of the Bauhaus, tried to create a genuine community of teachers and students who perform a common work oriented for the future. For the first time the student and the teacher co-created which was an alternative to the instructive method of traditional academic education in the field of applied art [4].

Innovative was the principle of combination of learning and craft proclaimed by W. Gropius: there is no fundamental difference between an artist and a craftsman, an artist is the highest level of a craftsman. W. Gropius identified two main goals of the teaching process: abandoning salon art, returning to craft - an application training as the basis of education". From the point of view of the Bauhaus professors the laws of excellence are obligatory for every artist. They are the source of true form-creation The training was conducted under the guidance of masters-teachers, representatives of advanced art trends of the beginning of the $\mathrm{XX}^{\text {th }}$ century. For the first time interactive pedagogical technologies began to be used in the educational process. The student group was given a professional task. It often was a real order by contract. Together with the master-teachers students searched for a project idea and methods for its implementation, comprehending all possible aspects of activities in the field of art and design creativity [5].

The form of preparing and passing the final qualification exam was also unusual. The work done by the student was esteemed by the council of teachers-masters of the school as well as invited specialists engaged in real production. The most prominent students were awarded the title of the master, the less successful students were apprentices. The principle of medieval guild craft guilds was taken as a basis. Soon the Bauhaus best practices found followers in all countries of the world. In Russia the first university of architecture and design was the Higher Art and Technical Studios (the VKHUTEMAS). The VKHUTEMAS and Bauhaus were in close cooperation exchanging methodological experience, teachers and students. Thus, almost a hundred years ago an idea of academic mobility was successfully implemented. In practice of the Russian design education the teaching technologies of the Bauhaus and VKHUTEMAS continue to develop and improve adapting to new sociocultural realities.

\section{RESULTS}

The results of the experience research of the Bauhaus and VKHUTEMAS formed the basis of the author's pedagogical methods of modern design education. At the Don State Technical University (the DSTU) the professional training of designers is also based on the educational concepts of two great schools, introducing an interactive teaching model in all disciplines of the professional cycle.

The main discipline that directly forms the professional competencies of the design student is "Design", it is didactically connected with all disciplines of the professional cycle. This discipline is cross-cutting in the educational process, takes place in all training courses. As a result of mastering of this discipline students consistently perform a number of course projects that are as close as possible in their professional tasks to real designing and design activities [6].

Designing is a way of implementation of a didactic task by means of systematic development of a problematic of a topic aimed at a specific practical result and presented by graphic means. Pre-designing includes an analysis of the design situation, the search for approaches and research methods, so that future designers form primary skills in research activities. As a result of the pre-project analysis, a design concept is developed that defines the artistic-figurative and constructivetechnological methods for solving the task. The design stage consists of creating a functional diagram of the design object, analysis of analogues, development of a composite solution, submitting the project and evaluating it. When performing design projects students solve a complex problem and use a set of methodological approaches, such as scientific, analytical, historical, search and research, compositional and other creative methods [7].

Within the framework of a general substantive task each student receives an individual project task for which he has to find his own approaches and solutions. The interaction of all participants in the course design process is organised like the work of a design team in production, and the role of the teacher is similar to that of a project manager. 
In the process of an artistic idea generating the most effective method is performing a clause. This short-term exercise on a given topic aims at finding a figurative solution to a topic that is new to a student. The most important criterion for the quality of the assignment is to find an original author's solution that would exist in the context of current trends in design practice, but had a pronounced sign of individuality. Clausura serves for development of students' figurative thinking, mobilizes knowledge and experience, develops imagination and compositional abilities. This is a kind of brainstorming: quick suggestions and solutions develop resourcefulness and determination and require intense attention, the work of thought and memory. Clause is performed without the help of the teacher, but with the obligatory discussion of the results individually or in a group [8].

Independent work is of great importance in the formation of student's active position in the educational process. This interactive teaching method implies individual work performed by a student without the participation of a teacher. Doing independent work helps the student to consolidate theoretical knowledge in practical activities; develops will and determination. In the process of this activity the student develops an ability to concentrate; memory develops, thinking trains, an ability to draw independent conclusions is formed.

The student often receives a creative design task for an independent work. Directional thematic sketch designing helps the student to think more productively, forms an inclination for new artistic ideas, develops creative abilities and imagination. Performing a series of creative tasks a student effectively consolidates the material studied in class and expresses his view of objects in the form of visual images, graphic signs. The results of creative homework are necessarily viewed and discussed in group classes. The task for students in this case is to present and defend their project idea. Moreover the assessment is given not only by the teacher, but also by student's groupmates.

A significant place in the professional training of studentsdesigners of the DSTU is occupied by practical trainings. Among them one of the most creative is the "workshop" practice. Its essence lies in the collective solution of professional tasks that require students not only to passively reproduce information, but also to make creative proposals on a given topic. Such tasks contain elements of uncertainty and, as a rule, have several approaches. During a workshop an active interaction of all members of the group take place where everyone can show initiative, independence and cognitive interest.

Usually in the framework of mastering the program of "workshop" creative training students carry out either an initiative project that doesn't involve implementation, but represents an interesting design task, or a project for a real customer. Most often the customer is educational and cultural institutions of the city of Rostov-on-Don, including various structures of the DSTU. This practical training fully simulates production processes and situations in the field of modern design. As a result students form one of their most important professional competencies that is an ability to analyze and determine the requirements for a design project and produce a set of possible solutions for a task or approaches to a design project [9].

The most important result of the creative workshop experience is public presentation of a project. The presentation can be prepared in the form of a poster presentation, in graphic form, in the form of a slide presentation and video presentation with the help of multimedia equipment. Presentation materials allow students to visualize the content of educational material, contribute to better consolidation of educational materials.

Another interactive technology used in the educational process of professional training of students-designers of the DSTU is a joint organizational activity for the preparation of creative events - social, exhibition and competition projects. Active participation in the preparation and conduct of such events teaches students to plan public events and forms the necessary professional competencies. Activity has two directions for students. One of them is the preparation of their own works for participation in professional exhibitions, contests, festivals. Another direction is connected with participation in the organization and conduct of events initiated by the University and the department. In this case students can act as authors of a concept of an event, developers of its identity, organizers of public relations, volunteers during events, etc. Any of these forms of activity helps to acquire "the baggage of knowledge and experience", increases creative independence, teaches to publicly present the results of one's work and fosters responsibility for his decisions [10].

\section{CONCLUSION}

All the above given interactive forms and teaching methods are successfully used by the DSTU teachers in the process of training design students. The author's methods and technologies based on rich international experience in design education and sensitively responding to the sociocultural demands of our time create a favorable environment for motivation and selfmotivation of students to obtain high-quality knowledge and skills in the professional field. This is confirmed by the high efficiency of the participation of the DSTU students in professional creative events of the all-Russian and international levels as well as the demand and competitive ability of graduates in the labor market.

Apart from the professional achievements the positive result of interactive teaching can be considered the inclusion of students in the public life of the University, city and country. Independence and responsibility are indispensable qualities of a person with an active civic position, whose upbringing is the paradigm of modern Russian education.

\section{References}

[1] [Federal State Educational Standard of Higher Education in specialty 54.03.01 Design (bachelor degree level), established by the order of the 
Ministry of Education and Science of the Russian Federation dated August 11, 2016, 1004. URL: http://fgosvo.ru/news/4/1911.

[2] Dvulichanskaya N. N. Interactive teaching methods as a means of forming key competencies. Science and Education: Electronic Scientific and Technical Edition. 2011, 1. URL: http://technomag.edu.ru/doc/172651

[3] Yakovleva N., Yakovlev E. Interactive teaching methods in contemporary higher education. Pacific Science Review. 2014, vol. 16, 2, pp. 75-80. URL: https://doi.org/10.1016/j.pscr.2014.08.016

[4] Milbrandt M., Milbrandt L. Creativity: What Are We Talking About? Art Education. 2015, vol. 64, 2011, 1, pp. 8-13. URL: https://doi.org/10.1080/00043125.2011.11519105

[5] Dunn, R. Learning styles: Theory, research, and practice. National Forum of Applied Educational Research Journal. 2000, vol. 13, 1, pp. 3-22.

[6] Lee Y.-J. A study on the effect of teaching innovation on learning effectiveness with learning satisfaction as a mediator. World Transactions on Engineering and Technology Education. 2011, vol. 9, 2, pp. 92-101.
[7] Segalowitz M., Chamorro- Koc M. Genuine Participation in Design Practice: Towards a Possible Metric. International Journal of Art \&amp; Design Education. 2017, vol. 37, 2. URL: https://doi.org/10.1111/jade.12102

[8] Ovchinnikova E.V., Zykov S.N. Clausura as a source of design and art solutions in design. Modern problems of science and education. 2015, 2-2. URL: https://science-education.ru/ru/article/view?id=22873

[9] Zimnaya I.A. Key competencies - a new paradigm of the result of education. Higher education today. 2003, 5, pp. 34-42.

[10]Berdnik T., I. Klimenko, L. Sayapina. Professional creativity competitions as a motivational tool in design education. The European Proceedings of Social \& Behavioural Sciences EpSBS. Published by the Future Academy. 2017. URL: http://dx.doi.org/10.15405/epsbs.2017.08.20

[11] Zinaida M. Kuznetsova, Yriy D. Ovchinnikov. Fatigue is a biomechanical category. The Russian Journal of Physical Education and Sport. 2018, vol. 13(1), pp. 134-138. DOI: 10/14526/01_2018_298 